\title{
PILIH PETANI VIETNAM ATAU PETANI INDONESIA? : PROTEKSI DAGANG PERTANIAN DALAM PERSPEKTIF EKONOMI POLITIK
}

\author{
Wahyu Riawanti \\ Universitas Gadjah Mada \\ e-mail: wahyuriawanti@yahoo.com
}

\begin{abstract}
ABSTRAK
This study emphasizes about Indonesian agricultural protection in international trade. This issue became prominent after the surge of imported products especially a decade after Indonesia followed what is instructed by IMF to liberalize international trade in most of commodities. The argument of tis studi is whether government execute the policy of agricultural protection in political economy perspective, considering that government not only needs to follow international tradeade regulation, but also require to protect any infant indistry with lack of technolog such as agriculture sector. This article focused in three main things: (1) protection of agricultural commodity is indeed difficult (2) the policy seemed make it it more complicated, (3) policy is about whose interest counts. Rice commodity is used to simplify the explanation with a brief comparation with other few commodities.
\end{abstract}

Keywords: political economy; trade protection; agricultural commodity; WTO regulation; food import

\section{PENDAHULUAN}

Pangan dan pertanian tidak bisa dipisahkan dari perdagangan internasional dengan semakin dekatnya globalisasi dengan kehidupan kita. Hal ini menyebabkan setiap kebijakan perdagangan internasional yang dilakukan pemerintah memberikan dampak baik langsung maupun dalam jangka waktu tertentu terhadap kehidupan masyarakat. Hal ini juga menggarisbawahi pentingnya masyarakat untuk mengetahui apa dan bagaimana perdagangan internasional dolakukan, apa peran WTO dan bagaimana regulasinya, dan yang paling utama adalah bagaimana pemerintah dapat berbuat sesuatu untuk mebuat masyarakat lebih baik dengan kebijakan ekonomi yaitu proteksi perdagangan.
Sektor pertanian harus menanggung beban sejarah masa lalu karena negara terlanjur meratifikasi Agreement of Agriculture dan menandatangani sejumlah perjanjian bilateral maupun multilateral dengan negara-negara lain. Beban pertama berupa kenyataan bahwa Indonesia berada dalam arus perdagangan internasional dengan peta kekuatan yang tidak seimbang antara negara maju dan berkembang. Beban tambahannya adalah regulasi perdagangan internasional tersebut cmemiliki kepentinag sendiri dan cenderung memihak kepentingan nagara maju. Untuk itulah mengapa kajian ekonomi politik ini penting dilakukan, karena gagasan utama ekonomi politik pertanian (terutama sebelum tahun 80an) adalah ketimpangan antara kondisi pertanian di negara maju dan berkembang yaitu dalam puzzle question (Swinnen, 2010) tentang mengapa 
petani negara maju disubsidi sedangkan petani negara berkembang justru dipajaki? Penelitian ini fokus pada (1) rekonfirmasi bahwa petani tidak cukup diproteksi, dan (2) temuan penelitian bagaimana proteksi dilakukan dan tidak pro-poor sebenarnya.

Artikel ini pada prinsipnya berargumen bahwa pemerintah tidak berpihak pada petani terdapat beberapa argumen: (a) bea masuk hampir nol, sehingga komoditas lokal sulit bersaing (b) kuota impor tidak diperlakukan serius (c) kebijakan pemerintah tidak berbasis produksi. Melihat kondisi di Indonesia, petani masih perlu diproteksi. Bahkan petani di AS diproteksi besarbesaran sampai menimbulkan kecemburuan sektor lain.

Pentingnya penelitian ini juga disebabkan karena menurut konsesi (Swinnen, 2010) banyak masalah kebijakan ekonomi tidak cukup dijelaskan dengan ilmu ekonomi, tetapi pendekatan ekonomi politik bisa memberikan telaah yang lebih mendalam karena adanya variabel kekuasaan dan self interest pembuat kebijakan yang mempengaruhi output kebijakan. Analisis ekonomi politik menekankan asumsi bahwa, karena kelangkaan sumber daya, tidak ada kebijakan politik yang bisa memuaskan semua pihak secara optimal sehingga pertanyaan mendasar dalam konteks ekonomi politik adalah whose interest counts yang merupakan pertanyaan normatif yang harus dijawab dalam kajian ilmu ekonomi politik dengan apa yang harus dilakukan oleh pemerintah (what should be set) (Shvets, 2010).

\section{REVIEW LITERATUR}

Kajian tentang ekonomi politik pertanian berawal dari pertanyaan tentang negara minimnya subsidi sektor pertanian pada negara berkembang. Karena peendekatan ekonomi politik selalu terkait dengan keberpihakan pemerintah dan self-interest kekuasaan pendekatan ekonomi politik tidak bisa dipisahkan dari kepentingan negara. Kajian ekonomi politik yang perlu dipertimbangkan sebagai landasan kajian ini adalah argumen (Downs, 1957) tentang berkurangnya jumlah pelaku pertanian yang menyababkan turunnya perhatian para pemilih sehingga dikenal istilah rationally skeptical voters. Pada kisaran tahun 70an akhir muncullah yang disebut sebagai the new political economy dari The University of Chicago. Pada periode ini kajian ekonomi politik mengritisi tentang kurangnya pemerintah negara berkembang dalam memberikan perhatian pada sektor pertaniannya misalnya Kenya (Bates, 1979) dan Bangladesh (Krueger, 1974)

Perkembangan kajian ekonomi politik mengalami masa yang paling dinamis dan produktif pada tahun 80an sampai menjelang pertengahan 90an. Pada periode ini perhatian utama kajian ekonomi politik pertanian terletak pada proteksi dan distorsi kebijakan. Kajian dan penelitian ekonomi politik pertanian setelah tahun 2000 berkembang pada banyak kajian sampai dengan peran media masa. Sepanjang tahun ini banyak bukti empiris dan dataset yang dapat dijadikan kajian untuk mengembangkan teori ekonomi politik dengan lebih leluasa. Salah satu rangkaian penelitian yang penting dilakukan oleh Kym Anderson (2008a; 2008b; 2009) yang menyajikan dataset komprehensif tentang proteksi dan distorsi kebijakan pertanian. Hasil kajian komprehensif ini akan menjadi tolok ukur pembahasan proteksi dalam artikel ini.

\section{Peta Kekuatan Indonesia}

Kebijakan pangan pada saat ini merupakan bagian dari proses globalisasi yang sangat masif dan ketergantungan terhadap negara lain. Teori Ketergantungan dapat dijelaskan dengan melihat perkembangan dunia pertanian dalam usahanya untuk mengikuti kecepatan gerak globalisasi melalui perdagangan bebas. Globalisasi yang tidak dapat dihindari sekaligus menyebabkan dampak ketergantungan antara negara yang sulit dihindari. 
Salah satu faktor yang menentukan kebijakan impor beras adalah disparitas harga lokal dan internasional. Impor beras dari negara ASEAN terutama Thailand mengalami peningkatan jumlah dalam jumlah yang signifikan. Sejak 1997 impor beras dari Thailand mencapai 30\% dari total impor beras Indonesia. Sementara itu regulasi perdagangan internasional yang dibuat oleh lembaga perdangana resmi World Trade Organization sangat dipengaruhi oleh negara penyandang dana terbesar lembaga tersebut terutama Amerika Serikat, Uni Eropa dan Kanada (Apriliani, 2012) sehingga negara tersebut akan mengusung kepentingannaya dalam penyusunan regulasi.

Hal ini menjadi awal masalah kebijakan pangan sejak IMF memberi rekomendasi kepada pemerintah Indonesia pasca pemberian pinjaman setelah krisis moneter pada tahun 1998 yaitu dengan mensyaratkan supaya Indonesia membuka keran impor termasuk untuk impor pangan. Hal ini berakibat membanjirnya komoditas impor pada tahun 1999 sehingga terjadi surge impor yang menyebabkan Nilai Tukar petani berada pada titik sangat rendah. Pada tahun ini bahkan terjadi pelanggaran re-ekspor karena pemerintah Indonesia mengimpor beras terklalu banyak sehingga harus mengekspor ke Afrika Selatan.

Setelah hampir 15 tahun dari tekanan IMF tersebut, pemerintah menghadapi dilema impor pangan yang berkepanjangan. Harga beras impor menjadi sangat bersaing dengan beras lokal. Pada titik ini, intervensi pemerintah sangat diperlukan. Pada titik ini pula keseriusan pemerintah untuk berpihak pada masyarakat miskin dapat ditakar dengan jelas. Pemerintah tidak bisa membiarkan distribusi pangan diserahkan pada mekanisme pasar.

Perdagangan dunia yang diatur oleh World Trade Organization menyebabkan impor pangan menjadi lebih mudah, IMF menyebabkan tarif $0 \%$, dan WB dengan sukses menggoalkan kebijakan raskin yang menyebabkan kebutuhan stok membengkak. Pada titik ini, ketika bangsa Indonesia menjadi bagian dari dunia global, maka petani tidak bisa menolong dirinya sendiri untuk berdaulat, karena negara membuatnya menjadi bagian dari globalisasi sehingga apa yang dimakan petani didapatkan dari proses globalisasi tersebut. Meskipun demikian hal ini sangat debatable dalam tataran kebijakan proteksi apa yang masih bisa dilakukan. Sebagian ahli berpendapat kebijakan proteksi tidak bisa terus menerus dilakukan karena masyarakat termasus petani produsen tidak selamanya dilindungi oleh pemerintah. Kenyataannya adalah tidak mungkin menghentikan proteksi karena selama ini hampir tidak pernah diproteksi seperti dalam petikan wawancara dengan Wahono berikut:

... masalah perdagangan pertanian adalah masalah aturan... tidak peduli kita mau menghasilkan produk sebaik apa, maka jika WTO menetapkan aturan yang menguntungkan negara maju (menjelaskan dengan simulasi kertas rokok) maka produk kiuta tidak akan pernah bersaing di dunia internasional

Pemerintah tidak bisa menganggap perdagangan dunia sebagai suatu hal yang tidak bisa diubah sehingga melepas tanggung jawabnya atas kesejahteraan petani yang telah "diglobalkan". Kebijakan pasca Agreement of Agriculture di negara Vietnam adalah contoh tepat sebagai komparasi kebijakan di Indonesia. Kebijakan Doi Moi yang merupakan kebijakan secara komprehensif untuk meningkatkan kesejahteraan rakyat Vietnam telah menunjukkan bukti bahwa negara berkembang melakukan emergency response terhadap perdagangan bebas. Terlepas dari kajian tentang kelamahan kebijakan tersebut, Doi Moi telah membawa bangsa Vietnam "from importer turns to exporter" dalam komoditas beras. Di Indonesia, sayangnya berlaku hal yang sebaliknya.

Sesuai dengan pembahasan pada babbab sebelumnya, maka penyebab utama kondisi 
Indonesia "dari eksportir menjadi importir" beras adalah penyelenggara negara corrupted dan kenyataan bahwa regulasi perdagangan yang berpihak pada negara maju. Hal ini adalah refleksi dari gambaran kondisi pemerintah dan bangsa Indonesia yang terpaksa mengikuti semua perangkat globalisasi, dalam aturan sering dirugikan dan dimanfaatkan oleh negara maju, dan secara ironis dilemahkan dari dalam oleh bangsa sendiri.

Menurut Bhagwati dan Srinivasan (1980) kebijakan ekonomi (komersial) merujuk pada tiga hal yaitu (1) tariff (quota) seeking, (2) tariff (quota) evasion, dan (3) rent seeking dan lobbying. Tariff (quota) seeking adalah adalah usaha memberlakukan tarrif (bea masuk) untuk mendapatkan keuntungan sebanyak mungkin dalam melakukan aktivitas perdagangan melalui ekspor-impor. Jika tarrif diberlakukan untuk alasan proteksi (misalnya bea masuk beras 340/ $\mathrm{kg}$ ), maka pihak yang diuntungkan dengan pemberlakuan tarif ini (beneficiaries) --yaitu petani atau organisasi petani-- akan melakukan lobby kepada pemerintah untuk mengamankan posisi mereka.

Sebaliknya, tariff (quota) evasion atau juga disebut smuggling. Ketika diberlakukan tarrif terhadap suatu komoditas, maka akan ada usaha untuk menghindari tarrif tersebut. Dalam hal bea masuk impor beras, pihak importir beras akan melobby pemerintah untuk meniadakan bea masuk untuk meminimalisir biaya impor. Dalam kasus di Indonesia, pemberlakuan bea masuk juga menyebabkan peningkatan impor beras ilegal. Jadi, dalam implementasinya akan terjadi: (a) penerimaan revenue pemerintah yang sayangnya belum tentu akan masuk kantong pemerintah, (b) peningkatan impor ilegal jika dibandingkan jika tidak ada bea masuk, yang menyebabkan kerugian negara, dan (c) terjadi hidden number yang mengacaukan perhitungan statistik.

Dalam kasus impor beras di Indonesia hal ini terjadi dalam kurun waktu 2001-2005 yaitu kasus pelanggaran sebagai berikut: (a) peningkatan jumlah impor ilegal dalam kurun waktu diberlakukannnya bea masuk, (b) penggelapan bea masuk oleh INKUD/ Nurdin Halid, dan (c) perbedaan jumlah data impor dari institusi berbeda. Masi demikian, hal menarik lainnya adalah bahwa Bhagwati (1982) menunjukkan sikap tegas pada penegakan aturan dan kemandirian ekonomi suatu negara sehingga mengharamkan "manipulasi aturan perdagangan" dan sekaligus menolak cara-cara negara berkembang dalam memohon mohon institusi perdagangan agar memberikan keringanan.

Pembahasan tentang aturan perdagangan tersebut dalam kajian ini menjadi concern terhadap "manipulasi aturan perdagangan", dan dipisahkan dari bab lain karena cakupannya yang cukup luas. Dalam penelitiannya tentang gerakan agraria di Indonesia, Tuong Vu (2009) mengkonfirmasi bahwa protes organisasi petani yang paling sering adalah mengenai aturan perdagangan bebas, isu impor beras dan lembaga keuangan internasional. Gerakan agraria pasca reformasi dinilai tidak cukup didukung oleh elit politik di mana keputusan yang dibuat parlemen masih tetap jauh dari undang-undang dan regulasi pertanian yang spesifik.

Konfirmasi yang sama dinyatakan oleh Jhamtani tentang kebijakan beras dan pangan yang selalu terkait dengan lembaga internasional dan negara maju karena garis kebijakan ekonomi dan pangan yang diambil pemerintah Indonesia tidak pernah lepas dari pengaruh lembagalembaga tersebut. Dominasi negara maju ini juga terjadi pada saat perundingan WTO di Doha pada 1995 yang dihadiri Hira Jhamtani yang menjelaskan bagaimana peta kekuatan utusan negara berkembang berikut:

.... saya yakin kita punya cukup banya orang yang bisa mewakili di dunia internasional. Masalahnya, tidak ada komitmen pejabat negara. Pada saat utusan Indonesia berunding tentang 
perdagangan dunia, utusan dari Amerika Serikat justru tahu lebih dahulu tentang apa yang sudah diputuskan oleh Menteri Perdagangan di Jakarta...

WTO sebagai organisasi perdagangan dunia menyaratkan liberalisasi perdagangan dan mengaturnya dengan mekanisme regulasi yang sebenarnya masih memberikan sedikit ruang kepada negara berkembang untuk memproteksi sebagaian produk pertanian yang strategis. Aturan ini diantaranya mengenai Special Product (SP) dan Special Safeguard Mechanisme (SSM). Meskipun demikian dalam banyak keputusan perdagangan garis kebijakan tetap didominasi oleh empat negara yaitu Amerika Serikat, Uni Eropa, Kanada dan Jepang.

Melalui Letter of Intent, IMF mensyaratkan liberalisasi perdagangan sebagai syarat pemberian kredit kepada Indonesia. Pasca diterbitkannya LoI ini, perkembangan liberalisasi pasar Indonesia berkembang begitu cepat dan menyebabkan Indonesia berpredikat salah satu negara berkembang yang paling banyak membuka pasar. Hal ini mengakibatkan serbuan impor temasuk komoditas pertanian mulai tahun 1999. Meskipun aturan WTO memperbolehkan penerapan pajak impor sampai $160 \%$, Indonesia hanya mengenakan pajak ini sebesar $20 \%$ sampai $30 \%$ untuk gula dan beras. Hal ini menyababkan membanjirnya barang impor dengan harga yang sulit disaingi produk lokal.

Sementara itu Organization For Economic Cooperation and Development (OECD) pada Oktober 2012 memberikan tiga rekomendasi terkait peningkatan ketahanan pangan (OECD, 12 Oktober 2012). Rekomendasi tersebut antara lain dengan memfasilitasi penanaman modal pertanian yang lebih tinggi, membuka lebih luas pasar produk pertanian dalam perdagangan internasional, mereformasi skema subsidi input dan bantuan pangan serta mulai meninggalkan tujuan swasembada pangan.

Menurut OECD, proteksi terhadap impor akan menghambat daya saing sektor pertanian, membatasi pertumbuhan produktivitas pertanian dan meningkatkan biaya pangan untuk konsumen miskin, termasuk mayoritas petani yang merupakan pembeli neto (net buyer) bahan pangan pokok. Lebih lanjut disampaikan bahwa kebijakan non tarif yang lebih terbuka akan mendorong perdagangan dan memungkinkan konsumen Indonesia mengakses pangan di pasar internasional dengan baik.

Daripenjelasantersebut dapat disimpulkan bahwa membuka impor pangan sebesar-besarnya dan melupakan mimpi swasembada pangan adalah inti dari rekomendasi tersebut. Dengan demikian isu swasembada dan kedaulatan pangan hanyalah semangat di basis petani sebagai produsen saja. Dengan perhitungan efisiensi ekonomi, tidak ada lembaga keuangan internasional yang tidak menyarankan kebijakan pangan murah. Hal ini menunjukkan kenyataan posisi ketergantungan negara ini terhadap bangsa lain.

Theotonio dos Santos dalam Budiman (1997) memberi definisi teori ketergantungan sebagai suatu keadaan dimana kehidupan ekonomi negara-negara tertentu tersebut hanya berperan sebagai penerima akibat saja. Hubungan saling tergantung antara dua sistem ekonomi ini dengan perdagangan dunia menjadi hubungan ketergantungan bila ekonomi beberapa negara (yang dominan) bisa berekspansi dan berdiri sendiri, sedangkan ekonomi negara-negara lainnya (yang tergantung) mengalami perubahan hanya sebagai akibat dari ekpansi tersebut, baik positif maupun negatif. Meski demikian, untuk kasus di Indonesia tidak berarti penutupan keran impor harus dijalankan dan berhenti nerkembang.

Hal ini sebenarnya bertentangan dengan defense penganut Teori Ketergantungan yang dalam rangka menentang tesis Marx mengatakan bahwa negara-negara pinggiran pra-kapitalis memiliki dinamikanya sendiri, dan jika tidak disentuh negara kapitalis akan berkembang sendiri, justru karena sentuhan negara kapitalis maju ini maka perkembangan negara pinggiran 
jadi terhambat. Teori Marxis klasik dan Teori Ketergantungan memiliki hal yang sama dalam konsep bahwa negara pinggiran ini akan berkembang mengikuti jejak negara kapitalis maju (Marx), atau justru perkembangannya menjadi terhambat karena pengaruh negara kapitalis.

Dengan demikian, pembahasan teorisasi ini akan lebih merujuk pada teori ketergantungan yang lebih spesifik pada gagasan kepentingan suatu negara menurut Keohane (Staniland, 2003). Robert Keohane mempertanyakan asumsi adanya ketidaksepakatan antara para pejabat dan institusi dalam mendefinisiskan "kepentingan nasional" sehingga demi tujuan pemahaman harus dilakukan eksplorasi konflik-konflik tersebut untuk suatu perspektif yang memandang bahwa setiap bangsa dan negara seharusnya menjadi aktor dengan hak-haknya sendiri. Konsep tentang menjadi aktor dengan hak sendiri adalah inti dalam pembahasan kebijakan kedaulatan pangan.

Perspektif ini adalah yang paling utama sehingga setiap sektor sosial termasuk buruh dan petani memiliki pilihan atas transaksi politik yang telah dilakukan, dan tidak sekedar menjadi pihak yang menanggung resiko social loss dari kebijakan. Kondisi ideal ini hanya mungkin terjadi apabila didukung oleh konsep yang memandang bahwa setiap bangsa dan negara menjadi aktor dengan haknya masing-masing.

\section{Anak Manis di Bawah Dominasi Negara Maju}

Dominasi negara maju dalam diskursus institusi internasional secara intens dibahas oleh Kohaene (1989:120) tentang peran institusi buatan Bretton Woods Conference 1944 seperti dalam petikan berikut:

... understanding the value of governmental openness for making mutually beneficial agreements helps to account for the often-observed fact that effective international regimes - such as the GATT in its heydey, or the Bretton Woods international monetery regime- are often associated with a great deal of informal contact and communication among officials...

Hal tersebut menjelaskan kepentingan negara maju dalam institusi internasional dan keberpihakan pada kebijakan yang dihasilkan. Rejim institusi internasional selalu memiliki kepentingannya sendiri dan tidak semua tindakannya semata-mata karena sifat altruistic (Apriliani, 2012). Apabila pemerintah masih menjadikan kedaulatan sebagai pijakan, maka menurut konsesi kedaulatan pangan makan harga komoditas pertanian dan akses pasar harus disesuaikan.

Harga produksi pertanian dalam ketahanan pangan semata-mata ditentukan oleh harga pasar (what the market dictates), sementara dalam kedaulatan pangan, harga harus adil dan tidak lebih rendah dari dari biaya produksi, serta mampu menjamin kehidupan petani dan buruh tani yang bermartabat. Akses pasar di dalam konsep ketahanan pangan adalah akses pasar luar negeri, sedangkan konsep kedaulatan pangan mensyaratkan akses pada pasar lokal, agar petani bisa menggantikan penguasaan oleh perusahaan agribisnis

Meskipun demikian kedaulatan bangsa dalam hal pangan juga bukan berarti pelarangan impor. Bahkan jika perlu dilakukan pembatasan impor, maka analisis ekonomi politik harus dapat memastikan kelompok mana yang akan diuntungkan. Dalam penelitian mendalam tentang proteksi beras dan tingkat kemiskinan (Basri dan Patunru, 2009) disimpulkan bahwa dalam hal proteksi beras ditemukan dua temuan yaitu (1) demand akan proteksi akan meningkat dengan naiknya nilai tukar (Rupiah) efektif naik, dan (2) net-consumer termasuk petani kecil merupakan kelompok yang paling dirugikan (less incentives) dan sejumlah kecil petani produsen (land owner) justru akan diuntungkan.

Dominasi negara maju terhadap negara berkembang adalah rahasia umum dalam World 
Trade Organization. Apakah suatu negara diuntungkan atau tidak oleh organisasi ini, ditentukan oleh klausul regulasinya. Negara maju memberikan subsidi dalam jumlah besar dan membuat negara berkembang dan melakukan lobby dan pendekatan untuk bisa mengekspor pangan ke negara berkembang dan berujung pada ketergantungan pangan impor.

Tabel 1. Tingkat Ketergantungan Impor (TKI) Pertanian 1999- 2010

\begin{tabular}{|c|c|c|c|c|c|c|}
\hline \multirow[t]{2}{*}{ Komoditas } & \multicolumn{3}{|c|}{ Tahun 1999} & \multicolumn{3}{|c|}{ Tahun 2010} \\
\hline & $\begin{array}{c}\text { Impor } \\
\text { (kal/ } \\
\text { kap/ } \\
\text { hr) }\end{array}$ & $\begin{array}{c}\text { Prod DN } \\
\text { (kal/kap/ } \\
\text { hr) }\end{array}$ & $\begin{array}{l}\text { TKI } \\
(\%)\end{array}$ & $\begin{array}{c}\text { Impor } \\
\text { (kal/ } \\
\text { kap/ } \\
\text { hr) }\end{array}$ & $\begin{array}{c}\text { Prod DN } \\
\text { (kal/kap/ } \\
\text { hr) }\end{array}$ & $\begin{array}{l}\text { TKI } \\
(\%)\end{array}$ \\
\hline \multicolumn{7}{|l|}{$\begin{array}{l}\text { Pangan } \\
\text { Nabati }\end{array}$} \\
\hline -Beras & 235,42 & $1.740,20$ & 13,53 & 33,86 & $1.437,75$ & 2,30 \\
\hline -Jagung & 27,00 & 425,20 & 6,35 & 62,82 & 491,22 & 11,34 \\
\hline -Kedelai & 67,84 & 139,91 & 48,49 & 58,79 & 91,34 & 91,34 \\
\hline $\begin{array}{l}\text {-Kacang } \\
\text { Tanah }\end{array}$ & 6,37 & 47,17 & 13,50 & 5,32 & 53,18 & 9,09 \\
\hline -Ubi Kayu & - & 294,65 & - & - & 324,35 & - \\
\hline -Ubi Jalar & - & 28,38 & - & - & 29,53 & - \\
\hline -Sayuran & 0,55 & 19,12 & 2,86 & 2,59 & 38,93 & 6,65 \\
\hline $\begin{array}{l}\text {-Buah- } \\
\text { buahan }\end{array}$ & 0,31 & 66,03 & 0,47 & 0,25 & 90,49 & 0,28 \\
\hline $\begin{array}{l}\text {-Minyak } \\
\text { goring }\end{array}$ & - & 204,28 & - & - & 446,04 & - \\
\hline -Gula & 99,46 & 124,40 & 79,95 & 31,39 & 124,46 & 25,22 \\
\hline \multicolumn{7}{|l|}{$\begin{array}{l}\text { Pangan } \\
\text { Hewani: }\end{array}$} \\
\hline $\begin{array}{l}\text {-Daging } \\
\text { sapi }\end{array}$ & 0,31 & 6,74 & 4,62 & 2,25 & 8,91 & 25,23 \\
\hline $\begin{array}{l}\text {-Daging } \\
\text { ayam }\end{array}$ & 0,17 & 13,26 & 1,25 & 0,02 & 23,44 & 0,09 \\
\hline $\begin{array}{l}\text {-Telur } \\
\text { S }\end{array}$ & - & 12,62 & - & - & 20,19 & - \\
\hline -Susu & 6,86 & 9,31 & 73,66 & 10,01 & 12,05 & 91,31 \\
\hline -Ikan & 0,58 & 45,81 & 1,26 & 1,45 & 53,71 & 2,70 \\
\hline
\end{tabular}

Sumber:Wahono, 2011

Nasib pangan dan pertanian di Indonesia bisa dilihat dari perkembangan ekspor-impor dan Tingkat Ketergantungan Impor (TKI) komoditas pertanian dalam jangka waktu sesudah 1999 sampai dengan tahun 2011 (Tabel 18). Tidak seperti Malaysia, Indonesia dengan senang hati menerima bantuan IMF dengan segala konsekuensinya. Mengapa Amerika melalui World Bank bersikukuh membujuk Indonesia supaya menerapkan kebijakan raskin demi pangan murah, jawabannya ada dua kemungkinan. Yang pertama adalah murni untuk melindungi rakyat yang merupakan net-consumer, tetapi jawaban kedua bisa jadi adalah alasan politis sebagai negara eksportir beras terbesar ke-3 di dunia. Meskipun selama 1998-2012 Amerika bukan sumber utama beras impor Indonesia, jumlah beras yang diekspor Amerika sebanyak 9 juta metrik ton per tahun adalah alasan yang masuk akal karena Indonesia adalah pasar potensial dalam hal pangan.

\section{Beras Petani dalam "Kotak Biru"}

Untuk melindungi komoditas pertanian, pemerintah bisa melakukan subsidi bagi produk lokalnya. Dalam regulasi perdagangan dunia subsidi domestik dibagi ke dalam dua kategori. Kategori pertama adalah subsidi domestik yang tidak terpengaruh atau kalaupun ada sangat kecil pengaruhnya terhadap distorsi perdagangan (Green Box) sehingga tidak perlu dikurangi dan kategori kedua adalah subsidi domestik yang mendistorsi perdagangan (Amber Box) sehingga harus dikurangi sesuai komitmen. WTO mensyaratkan beras di negara Asia berada dalam kotak ini dan WB menyarankan besaran subsidi harus dibatasi, sehingga berakibat dihentikannya subsidi pupuk bagi petani.

Kategorisasi barang komoditas yang bisa disubsidi dilakukan oleh oleh WTO dengan melakukan pengaturan komoditas sesuai klasifikasi boxes. Klasifikasi tersebut sering dimanipulasi selalu lebih menguntungkan negara maju karena mereka bisa memberikan subsidi dalam jumlah besar bagi petani mereka dan membatasi subsidi negara berkembang untuk petaninya (Wahono 2008: 37 dan Jhamtani 2004:24). Untuk menyiasati hal tersebut 
pemerintah Indonesia dapat mencari celah dari aturan terkait karakteris komoditas dalam tabel berikut:

Tabel 2. Regulasi WTO untuk Subsidi Domestik Sektor Pertanian

\begin{tabular}{|c|c|l|}
\hline No & Boxes & \multicolumn{1}{|c|}{ Keterangan } \\
\hline 1 & $\begin{array}{c}\text { Amber } \\
\text { Box }\end{array}$ & $\begin{array}{l}\text { semua subsidi domestik yang } \\
\text { dianggap mendistorsi produksi dan } \\
\text { perdagangan. }\end{array}$ \\
\hline 2 & Blue Box & $\begin{array}{l}\text { amber box dengan persyaratan } \\
\text { tertentu yang ditujukan untuk } \\
\text { mengurangi distorsi. Subsidi yang } \\
\text { biasanya dikategorikan sebagai } \\
\text { Amber Box akan dimasukkan ke } \\
\text { dalam Blue Box jika subsidi tersebut } \\
\text { juga menuntut dikuranginya produksi } \\
\text { oleh para petani }\end{array}$ \\
\hline 3 & Green & $\begin{array}{l}\text { subsidi yang tidak berpengaruh } \\
\text { atau kalaupun ada sangat kecil } \\
\text { pengaruhnya terhadap perdagangan. } \\
\text { Subsidi tersebut harus dibiayai dari } \\
\text { anggaran pemerintah (tidak dengan } \\
\text { membebani konsumen dengan harga } \\
\text { yang lebih tinggi) dan harus tidak } \\
\text { melibatkan subsidi terhadap harga }\end{array}$ \\
\hline
\end{tabular}

Sumber: Biro Kerjasama Perdagangan Luar Negeri, Kementan.

Selama periode 2010 Indonesia bahkan melakukan 7 pelanggaran karena komoditas pangan ditolak dengan alasan regulasi kotak amber (Deperindag, 2011). Kebijakan ini harus dilihat secara komprehensif, apakah pelanggaran dilakukan karena aturan yang tidak memihak atau semata-mata pelanggaran teknis tertentu karena tidak memenuhi Standard Operating Procedure. Dominasi negara maju juga dibuktikan dengan tindakan responsif yang dilakukan duta besar pemerintah Amerika dan Australia pada saat diumumkan tentang pengurangan kuota impor daging.

\section{HASIL PENELITIAN DAN PEMBAHASAN}

Pembahasan produk pangan komoditas impor adalah penjabaran masalah terkait proteksi perdagangan. Proteksi perdagangan adalah kewajiban negara dan sangat ditentukan oleh komitmen politik penguasa. Pada kondisi pasar sempurna, ekonomi tanpa regulasi bisa dijalankan oleh para pengambil kebijakan ekonomi. Bahkan penganut ekonomi politik klasik beranggapan bahwa keterbelakangan ekonomi merupakan akibat aktivisme (intervensi) negara.

Dalam kaitan aspek pertanian, di satu sisi secara empiris pelarangan impor pangan juga dapat diartikan sebagai pelanggaran hak asasi karena masyrakat memiliki hak untuk mendapatkan barang atau jasa yang berkualitas dengan harga lebih murah. Menurut ekonom klasik dan neo klasik, jika konsep anti-persaingan dipraktikkan, akan terjadi inefisiensi ekonomi dan kesejahteraan masyarakat sulit diciptakan. Meskipun demikian proteksi perdagangan wajib diberikan sebagai perlindungan bagi infant industry. Hal ini adalah alasan yang qualified dan akan ditempuh negara manapun untuk melindungi sektor yang lemah.

\section{Proteksi melalui pembatasan kuota impor}

Negara tidak bisa menegasikan perdagangan bebas dalam globalisasi karena secara teoritis perdangan bebas dilakukan untuk meningkatkan produktivitas dan pendapatan produsen serta mencapai social utility yang tingi bagi konsumen. Perdagangan bebas diharapkan akan mendorong adanya persaingan antar negara sehingga lebih efisien serta adanya persaingan sempurna yang memenuhi pareto optimal. Meskipun demikian aturan kebijakan yang diterapkan selain bertujuan untuk mendapatkan keuntungan, pada saat yang sama dijalankan sesuai tujuan pemerintah dalam fungsinya sebagai negara. 
Keberpihakan pemerintah kemudian dapat diukur dari instrumen kebijakan perdagangan yang diberlakukan termasuk kuota impor. Penetapan kuota impor adalah suatu bentuk kebijakan pemerintah dalam hambatan non tarif (non tariff barriers) yang dilakukan untuk membatasi masuknya barang dan jasa. Dan ini bukan satusatunya mekanisme yang bisa dilakukan pemerintah untuk melindungi petani, tetapi dapat dilakukan melalui scientific tarrif dan melindungi pasar domestik. Meskipun demikian perlindungan pasar domestik bisa berakibat pemanfaatan sumber daya domestik tidak efisien (Dasgupta, 2010).

Tabel 3. Dampak Kebijakan Perdagangan Pertanian

\begin{tabular}{|l|l|l|l|l|}
\hline \multicolumn{5}{|l|}{ Jenis kebijakan Perdagangan } \\
\hline & Tarif & $\begin{array}{l}\text { Kuota } \\
\text { Impor }\end{array}$ & $\begin{array}{l}\text { Subsidi } \\
\text { Ekspor }\end{array}$ & $\begin{array}{l}\text { Voluntary } \\
\text { Impor } \\
\text { Restriction }\end{array}$ \\
\hline $\begin{array}{l}\text { Surplus } \\
\text { Produsen }\end{array}$ & Meningkat & Meningkat & Meningkat & Meningkat \\
\hline $\begin{array}{l}\text { Surplus } \\
\text { konsumen }\end{array}$ & Turun & Turun & Turun & Turun \\
\hline $\begin{array}{l}\text { Pendapatan } \\
\text { pemerintah }\end{array}$ & Meningkat & $\begin{array}{l}\text { Turun } \\
\text { (Belanja } \\
\text { pemerintah } \\
\text { naik) }\end{array}$ & $\begin{array}{l}\text { Tidak } \\
\text { berubah } \\
\text { (Rente bagi } \\
\text { pemilik } \\
\text { lisensi) }\end{array}$ & $\begin{array}{l}\text { Berubah } \\
\text { (Rente bagi } \\
\text { pemilik } \\
\text { lisensi) }\end{array}$ \\
\hline $\begin{array}{l}\text { Kesejahteraan } \\
\text { Sosial }\end{array}$ & $\begin{array}{l}\text { Tidak pasti } \\
\text { (turun untuk } \\
\text { negara kecil }\end{array}$ & Turun & $\begin{array}{l}\text { Tidak Pasti } \\
\text { (turun untuk } \\
\text { negara } \\
\text { kecil) }\end{array}$ & Turun \\
\hline
\end{tabular}

Sumber: Basri dan Patunru, 2010

Argumen yang qualified untuk dilakukan proteksi adalah dengan alasan (a) Ketahanan nasional dalam industri strategis, karena industri perberasan menyangkut terhada seratus juta petani produsen (b) perdagangan yang tidak adil (unfair trade) yang disebabkan kaerana adanya subsidi negara lain terhadap komoditas yang sama. Sebagi contoh adalah beras impor Thailand, dan (c) infant industry, karena penguasaan teknologi yang masih rendah sehingga produsen perlu dilindungi. Argumen ini diperkuat dengan fakta akan ketidaksiapan Indonesia (Azahari, 2005) karena proses penggodokan SP dan SMM sampai mencapai kata sepakat di antara negara-negara G-33 membutuhkan waktu lama.

Meskipun bukti empiris jelas menunjukkan kita tidak siap, sejauh ini belum ada pengawasan dan keseriusan dalam menangani kuota impor. Dengan melihat siapa yang diuntungkan dengan masing-masing instrumen kebijakan tersebut, menjadi lebih mudah dipahami mengapa pemerintah setengah hati memberlakukan pembatasan impor beras karena instrumen kebijakan perdagangan diarahkan pada pangan murah yang menguntungkan konsumen. Kebijakan kuota impor bisa jadi akan menguntungkan petani produsen tetapi tidak akan meningkatkan citra pemerintah. Menjaga citra adalah salah satu self-interest pemerintah melalui setiap kebijakan yang diberlakukan.

Perdagangan pangan terkait langsung dengan Teori Ketergantungan. Meskipun kritik teori ketergantungan menekankan pada perbedaan negara maju dan negara pinggiran, di mana pengaruh kapitalis negara maju termasuk kerjasama perdagangan hanya akan menyebabkan negara miskin berhenti berkembang (Staniland, 2003), harus disadari fakta bahwa di luar komodias beras, terutama daging dan Indonesia masih tergantung pada produk pertanian dari negara maju yaitu Australia dan Amerika Serikat (AS).

Meskipun Indonesia tidak mengimpor beras dari AS, negara ini memiliki 9 juta metrik ton per tahun sebagai cadangan beras internasional. Mengingat kondisi beras di pasar internasional yang thin market, bisa dipastikan AS akan memperoleh keuntungan besar dengan memperluas pasar beras. Di Amerika, beras diproduksi di sejumlah negara bagian termasuk Texas, Sacramento dan Santa Cruz (The Creed Rice, 2011). Pemerintah sangat politis dalam hal pangan karena produk pertanian di AS yang luar biasa maju.

Penelitian Marion Nestle (1993) mengkaji tentang politik pangan AS untuk memastikan 
pemerintah memiliki pasar bagi produk pertanian. Sepanjang 1980 - 1990 dilakuka propaganda untuk mengkonsumsi lebih banyak daging dan gandum dengan cara memberi subsidi bagi makan siang di sekolah-sekolah pemerintah. Program jangka panjang ini tidak hanya menimbulkan protes dari sektor yang lain tetapi juga menyebabkan perubahan pola makan dan meningkatnya jumlah siswa dengan masalah obesitas pada awal tahun 90an.

Penelitian tersebut di sisi lain menunjukkan kuatnya posisi petani di AS sehingga kaum petani memiliki ruang untuk memperoleh subsidi dari pemerintah. Di sisi lain, kasus ini menjelaskan konsep rent seeking sebagai self-interest "positif" yang juga adalah pilihan individu dalam transaksi politik. Dalam transaksi politik tersebut, kelompok petani AS bisa memaksa pemerintah untuk membuat subsidi besar bagi sektor pertanian dan menyetujui program nasional untuk menciptakan "pasar" bagi komoditas tersebut.

\section{Kemandirian dalam Impian}

Salah satu kajian Bhagwati yang sangat menarik adalah tentang kemandirian suatu negara dala perdagangan. Menurutnya, ada sejumlah fallacy atau mitos tentang free trade yang sekian lama dipercaya oleh ekonom dan dunia perdagangan (Bhagwati dan Panagriya, 2010). Umumnya diyakini bahwa negara maju selalu merugikan negara miskin mulai dari pengaturan perdagangan di WTO sampai pada implementasi pengurangan tarrif yang tidak transparan. Kajian Bhagwati menemukan hal berlawanan yaitu terjadi kondisi sebaliknya, di mana negara berkembang justru memberikan proteksi lebih besar daripada negara maju.

Hal ini didukung dengan hasil penelitian sebelumnya oleh Finger dan Shukrecht (1994) yang melaporkan besaran proteksi sepanjang 1955 -1999 untuk tekstil oleh negara maju sebesar $8 \%$ dan negara miskin sebesar $21 \%$. Sementara itu tindakan anti dumping yang dilakukan negara maju sebanyak 463 kali dan sementara negara miskin sebanyak 559 kali. Kajian tersebut berakhir dengan kalimat kritis: "if you insist a free supper, you can not expect to eat a banquet". Bahwa ketika suatu negara memaksa untuk selalu mendapat kemudahan dalam regulai, maka dia tidak akan mendapatkan kemajuan dan pencapaian seperti negara yang mandiri.

Kecenderungan negara berkembang untuk menyalahkan negara maju dengan mengatakan tidak akan membebaskan tarrif di negaranya jika negara maju tidak melakukannya, menurut kacamata ekonomi tidak dibenarkan sama sekali (Bhagwati, 1990). Meskipun debat panjang masih dilakukan oleh sejumlah NGO barat dan aktivis gereja, menyalahkan negara maju juga tidak akan membantu negara berkembang.

Tabel 4. Nilai Impor dan Ekspor Beberapa Komoditas Pangan Indonesia

\begin{tabular}{|c|c|c|c|c|c|c|}
\hline \multirow[t]{2}{*}{ Komoditas } & \multicolumn{3}{|c|}{ Tahun 1999} & \multicolumn{3}{|c|}{ Tahun 2010} \\
\hline & $\begin{array}{c}\text { Impor } \\
\text { (kal/ } \\
\text { kap/ } \\
\text { hr) }\end{array}$ & $\begin{array}{l}\text { Prod DN } \\
\text { (kal/kap/ } \\
\text { hr) }\end{array}$ & $\begin{array}{l}\text { TKI } \\
(\%)\end{array}$ & $\begin{array}{c}\text { Impor } \\
\text { (kal/ } \\
\text { kap/ } \\
\text { hr) }\end{array}$ & $\begin{array}{c}\text { Prod } \\
\text { DN (kal/ } \\
\text { kap/hr) }\end{array}$ & TKI (\%) \\
\hline \multicolumn{7}{|l|}{ Pangan Nabati } \\
\hline -Beras & 235,42 & $1.740,20$ & 13,53 & 33,86 & $1.437,75$ & 2,30 \\
\hline -Jagung & 27,00 & 425,20 & 6,35 & 62,82 & 491,22 & 11,34 \\
\hline -Kedelai & 67,84 & 139,91 & 48,49 & 58,79 & 91,34 & 91,34 \\
\hline -Kacang Tanah & 6,37 & 47,17 & 13,50 & 5,32 & 53,18 & 9,09 \\
\hline -Ubi Kayu & - & 294,65 & - & - & 324,35 & - \\
\hline -Ubi Jalar & - & 28,38 & - & - & 29,53 & - \\
\hline -Sayuran & 0,55 & 19,12 & 2,86 & 2,59 & 38,93 & 6,65 \\
\hline -Buah-buahan & 0,31 & 66,03 & 0,47 & 0,25 & 90,49 & 0,28 \\
\hline $\begin{array}{l}\text {-Minyak } \\
\text { goreng }\end{array}$ & - & 204,28 & - & - & 446,04 & - \\
\hline -Gula & 99,46 & 124,40 & 79,95 & 31,39 & 124,46 & 25,22 \\
\hline \multicolumn{7}{|l|}{$\begin{array}{l}\text { Pangan } \\
\text { Hewani: }\end{array}$} \\
\hline -Daging sapi & 0,31 & 6,74 & 4,62 & 2,25 & 8,91 & 25,23 \\
\hline -Daging ayam & 0,17 & 13,26 & 1,25 & 0,02 & 23,44 & 0,09 \\
\hline $\begin{array}{l}\text {-Telur } \\
\text { S }\end{array}$ & - & 12,62 & & & 20,19 & \\
\hline -Susu & 6,86 & 9,31 & 73,66 & 10,01 & 12,05 & 91,31 \\
\hline -Ikan & 0,58 & 45,81 & 1,26 & 1,45 & 53,71 & 2,70 \\
\hline
\end{tabular}

Proteksi berlebihan ini dilakukan oleh negara negara Timur jauh untuk memperbaiki performans ekspornya. Menurut hasil penelitian 
Bhagwati sebelumnya, hal yang sama dilakukan oleh India dan justru mencederai kinerja ekspor sekaligus kondisi ekonominya.

Proteksi perdagangan untuk melindungi petani adalah pertanyaan besar bagi pemerintah Indonesia. Meskipun tingkat ketergantungan terhadap produk impor (TKI) untuk beberapa komoditas menurun, dengan mencermati besarnya jumlah impor (Tabel 14) bisa dipastikan bahwa belum cukup banyak proteksi yang telah dilakukan.

Keberpihakan kebijakan perdagangan komoditas pertanian bisa dibaca dengan pemberlakuan kebijakan turunan impor ekspor pangan yaitu: (1) subsidi pada jalur pengembangan untuk melindungi petani lokal, (2) pengaturan syarat yang lebih adil termasuk bea masuk impor, (3) pengaturan waktu impor terutama pada saat panen raya. Kebijakan turunan terkait impor produk pertanian telah mensyaratkan beberapa regulasi seperti: besaran bea masuk impor beras sebesar $\mathrm{Rp} 340 / \mathrm{kg}$, pembatasan jumlah impor pangan tertentu, pembatasan negara tertentu untuk daging dan susu dan penentuan pangan halal.

Tabel 5.

Tarif Masuk Pangan Impor 1995 - 2012

\begin{tabular}{|l|l|c|c|c|c|c|}
\hline \multirow{2}{*}{ No } & \multirow{2}{*}{ Komoditas } & \multicolumn{5}{|c|}{ Bea Masuk (\%) *) } \\
\cline { 3 - 7 } & & $\mathbf{1 9 9 5}$ & $\mathbf{1 9 9 7}$ & $\mathbf{1 9 9 8}$ & $\mathbf{2 0 0 3}$ & $\mathbf{2 0 1 2}$ \\
\hline 1 & Beras & 160 & 0 & 0 & $30 *)$ & 0 \\
\hline 2 & Tepung terigu & 40 & 5 & 5 & 0 & 0 \\
\hline 3 & Jagung & 40 & 0 & 0 & 0 & 0 \\
\hline 4 & Kedelai & 27 & 0 & 5 & 0 & 0 \\
\hline 5 & Sapi & 40 & 0 & 0 & 0 & 0 \\
\hline 6 & Daging sapi & 50 & 25 & 5 & 0 & 0 \\
\hline 7 & Susu powder & 210 & 5 & 5 & 0 & 0 \\
\hline 8 & Telur & 40 & 15 & 5 & 0 & 0 \\
\hline 9 & Ikan laut & 0 & 20 & 5 & 0 & 0 \\
\hline 10 & Jeruk & 50 & 0 & 5 & 0 & 0 \\
\hline 11 & Apel & 0 & 25 & 5 & 0 & 0 \\
\hline
\end{tabular}

*) ad valorem dalam regulasi WTO bisa mencapai $160 \%$ dari harga jual

**) 30\% atau sekitar $\mathrm{Rp} 430,-/ \mathrm{kg}$
Ketidakberpihakan pemerintah terhadap komoditas lokal sementara ini dengan alasan bahwa petani dan komoditasnya harus mendiri karena semua sektor harus menghadapi persaingan bebas. Masalahnya adalah bahwa komoditas Indonesia belum siap untuk ide besar globalisasi tersebut kecuali pelaku sektor pertanian dipersiapkan dari jauh hari. Hal ini menjawab pertanyaan besar yang sangat untuk negara berkembang (Bates, 1981) tentang apakah suatu negara miskin karena memang miskin, atau suatu negara menjadi miskin karena kebijakan yang salah. Penelitian terbarunya di negera-negara Afrika tentang climate change menunjukkan bahwa masalah sebenarnya bukan terletak pada cuaca yang sulit di prediksi, seperti yang selama ini dipercaya banyak pihak dan mengantar pada pernyataan berikut:

"... those who follow Africa are convinced that the problems lie way

deeper than the vagaries of the weather"...

Perubahan cuaca tersebut, dalam suatu penelitian di Nusa tenggara Timur Indonesia tentang kritik terhadap konsep ketahanan pangan yang tidak didukung produksi. Masyarakat $\mathrm{Ku}-$ pang menjadi tergantung dengan beras sedangkan produksi beras lokal tidak memungkinkan, sementara produksi pangan lokal tidak optimal karena kekeringan dalam jangka panjang (Lassa, 2008).

Paparan diatas menunjukkankompleksitas masalah pertanian di Indonesia. Dan masalah tersebut tidak bisa diselesaikan sendiri oleh pelaku di sektor pertanian. Karena masalah utama rendahnya produktivitas dan ketergantungan pada impor pangan disebabkan oleh kebijakan yang tidak menjawab inti persoalan pertanian sehingga insentif ekonomi bagi petani selalu rendah.

Konsensus umum yang disepakati adalah bahwa faktor utama rendahnya produktivitas pertanian tersebut disebabkan karena insentif yang diterima oleh petani produsen. Keterbatasan 
fisik dan biologis akan dapat diatasi selama tersedia insentif yang memadai. Dalam hal ini dikatakan oleh Theodore Schultz bahwa ketika kesempatan tersedia dan dengan insentif yang cukup petani akan dapat mengubah pasir menjadi emas:

Jika masalah utama pertanian adal kecilnya insentif, dengan demikian maka problem utama adalah pada perilaku mereka yang melemahkan atau mendistorsi operasi pasar. Dan sumber utama distorsi tersebut adalah kebijakan yang diadopsi pemerintah. Jadi, masalah terbesar negara dunia ketiga adalah kebijakan yang buruk. Kemampuan negara tersebut meningkatkan kualitas populasi dan ilmu pengetahuan (Schultz, 1980: 639). Meskipun demikian menurutnya sulit bagi kaum berada untuk mengerti perilaku orang yang hidup dalam kemiskinan.

Ketika reformasi agraria dan kepemilikan lahan diperjuangkan oleh pelaku pertanian, Scultz mngemukakan kritiknya tentang "kesalahan intelektual" oleh para ahli ekonomi yang memandang sektor pertanian dengan menganggap terlalu penting (overrate) kepemilikan tanah dan menihilkan (underrate) kualitas sumber daya manusia. Kedua kesalahan tersebut adalah (a) asumsi bahwa teori ekonomi standar dirasa cukup untuk memahami perilaku masyarakat di low-income countries, padahal diperlukan teori ekonomi yang terpisah, dan (b) pengabaian "sejarah ekonomi" dalam merencanakan pembangunan ekonomi suatu negara.

Pada kenyataannya, petani produsen tidak hanya menerima insentif ekonomi kecil, masyarakat kehilangan tetapi kesempatan kerja sebagai akibat social cost praktik rent seeking. Kebijakan pertanian yang tidak berbasis produksi adalah dukungan terhadap perampasan kedaulatan petani yang justru dilakukan oleh penyelenggara negara.

\section{Mengapa Pertanian Jalan di Tempat}

Kebijakan subsidi adalah bagaikan pedang bermata dua, selalu menyebabkan welfare closs dan deadweight loss. Dalam kajian ekonometrika, kebijaka subsidi selalu menyebabkan kegagalan pasar dimana informasi tidak terjadi secara sempurna dan cenderung menyebabkan terjdinya government failure karena kesalahan kebijakan yang diambil. Jika perhitungan kebijakan ini semata-mata atas bnama efisiensi, maka paket kebijakan jenis apapaun tidak akan menmberikan nilai efisiensi bagi pemerintah. Jika demikian maka pemerintah akan memakai hal ini sebagai excuse mengurangi subsidi pupuk dan pembebasan tariff impor beras. Kebijakan yang memulihkan pertanian adalah kebijakan jangka panjang yang memerlikan banyak biaya dan waktu lama untuk melihat hasilnya. Hal ini bukan merupakan karakter kebijakan yang diinginkan pemerintah untuk melihatkan citranya yang baik dan performance yang efisien. Citra baik dan performance efisien ini adalah self interst pemerintah yang seolah-olah menjadi interest bersama seluruh bangsa.

Self interest pemerintah tersebut menyebabkan pertanian jalan di tempat kondisi yang sudah ada: (1) landasan ekonomi yang rapuh warisan rezim Orba, (2) karakter pembangunan pertanian tidak berbasis produksi dan (3) kebijakan perdagangan tidak menyadari masahan pada kedua poin pertama.

Hasil penelitian tersebut menunjukkan bahwa secara empiris kebijakan proteksi dilakukan berdasakan kepentingan elit politik, atau kelas masyarakat tertentu, dalam hal ini kelas masyarakat pemilik kapital. Pembaca mendapat informasi baru bahwa (a) regulasi perdagangan menentukan nasib masyarakat sebagai konsumen dan sebagai warga negara, dan pembaca diyakinkan bahwa (b) masalah WTO dan pengaturan perdagangan adalah masalah bersama, bukannya menara gading yang hanya wajib diketahui pemerintah tetapi menyangkut hak warga negara. 


\section{KESIMPULAN DAN SARAN}

Kebijakan impor pangan berpusat pada pemerintah dan lebih peduli pada politik pencitraan dan laporania tidak selalu terjamin. Dalam hal ini yang dibutuhkan adalah ketegasan pemerintah untuk memihak pada kedaulatan pangan.

Kesimpulan dalam artikel ini adalah tentang pengaturan perdagangan yang hampir merupakan satu-satunya jalan keluar untuk melindungi petani karena:

Pemerintah tidak bisa menegasikan globalisasi dan mau tidak mau harus menaati regulasi perdagangan atau berhadapan dengan hukum perdagangan internasional.

Pelarangan impor adalah pelanggaran aturan yang sudah diratifikasi dan juga melanggar hak asasi manusia karena konsumen berhak akan pangan dengan harga yang terjangkau dan mudah diakses.

Regulasi perdagangan bukan sesuatu yang tidak bisa diubah, tetapi bisa diperjuangkan. Tentu saja hal ini harus terintegrasi dengan baik dengan aturan di ranah yang lain terutama penegakan hukum bagi segala bentuk pelanggaran dan tindak korupsi.

Singkatnya, ketika rent seeking dianggap pilihan individu yang positif dalam suatu transaksi politik, hal ini tidak didapatkan oleh petani Indonesia sebagai konstituen partai politik. Dan pada saat rent seeking didefinisikan sebagai kecenderungan pejabat politik untuk memanfaatkaan kemudahan pemerintah, importasi pangan menjadi sarat korupsi sehingga tiadanya pembatasan kuota impor menyebabkan produk petani lokal tidak bisa bersaing.

Saran dan Implikasi Kebijakan:

Ketegasan pemerintah untuk membenahi regulasi perdagangan pertanian. Regulasi given mata pada mesin pasar. Vietnam dan Malaysia adalah contoh pentingnya ketegasan pemerintah. Serta dengan transformasi total melalui penegakan hukum.

\section{DAFTAR PUSTAKA}

Ambardi Kuskridho, (2009). Mengungkap Politik Kartel : Studi tentang Sistem Kepartaian di Indonesia era Reformasi. Jakarta. Kepustakaan Populer Gramedia.

Khor, Martin. (2010). Memperdagangkan Kedaulatan: Free Trade Agreement dan Nasib Bangsa. Insist Press.

Purwanto, AE dan R. Dwisuliastuti, (2011). Jurnal JAKP. November 2011.

Riawanti, Wahyu. (2011). Kajian Ekonomi Politik State-centered dan Rent-seeking dalam Kebijakan Impor Beras. Jurnal Kebijakan dan Administrasi Publik UGM Vol 16 Peb 2011.

Riawanti, Wahyu. (2012). Kajian Ekonomi Politik Kebijakan Impor Daging Sapi Menuju Swasembada Daging. Dalam Indonesia Bergerak: Percik Pemikiran Komunitas Sekip untuk Perubahan. Editor Agus Pramusinto dan Erwan Agus Purwanto.

Sen, Amartya. (2000). Development As Freedom. Anchor Books. A Division of Random House. New York. 